\title{
Morphophysiological parameters of sugarcane leaf in response to the residual effect of agricultural gypsum on the ratoon
}

\section{Parâmetros morfofisiológicos da folha de cana-de-açúcar em resposta ao efeito residual do gesso agrícola na soqueira}

\author{
Paulo Alexandre Monteiro de FIGUEIREDO ${ }^{1 ; 2}$; Lucas Aparecido Manzani LISBOA ${ }^{3}$; Ronaldo da Silva \\ VIANA $^{4}$; Ana Carolina Nunes Domingues de ASSUMPÇÃO ${ }^{5}$; Anderson Chagas MAGALHÃES ${ }^{6}$ \\ ${ }^{1}$ Parte da tese de livre docência do primeiro autor \\ 2 Autor para correspondência; Professor Doutor; Universidade Estadual "Júlio de Mesquita Filho" - Unesp, Campus \\ Experimental de Dracena, 17900-000, Dracena, SP, Brasil. E-mail: paulofigueiredo@dracena.unesp.br \\ ${ }^{3}$ Mestre; Universidade Estadual Paulista “Júlio de Mesquita Filho" - Unesp; lisboa@dracena.unesp.br \\ ${ }^{4}$ Professor Doutor; Faculdade Tecnológica (FATEC); ronaldosdv@hotmail.com \\ ${ }^{5}$ Coordenadora de Estágios; Fundação Dracenense de Educação e Cultura (FUNDEC); anacndomingues@terra.com.br \\ ${ }^{6}$ Professor Doutor; Universidade Estadual Paulista “Júlio de Mesquita Filho" - UNESP; amchagas@dracena.unesp.br
}

Recebido em: 07-04-2014; Aceito em: 28-11-2014

\begin{abstract}
The sugarcane (Saccharum spp.) is a species of the Poaceae family extremely important for commercial cultivation in different parts of the world. This study aimed at evaluating the influence of applying different doses of gypsum in morphophysiological parameters of sugarcane. The experiment was conducted at Dracena Plant, located in Dracena, São Paulo in October 2007 in the fourth cycle of ratoon sugarcane. The experimental design was a randomized blocks with four replications. The treatments were five rates of gypsum: $0,1,2,4$ and $8 \mathrm{tha}^{-1}$ applied in the total area of the plot at the experiment installation. After harvesting the stems, leaves were collected to perform morphological analysis. The application of gypsum resulted in an increase in the number of stomata on the abaxial surface of the sugarcane leaves. The application of gypsum in the soil caused favorable changes in morphophysiology of ratoon leaves of sugarcane.
\end{abstract}

Additional keywords: plant morphology; plant physiology; Saccharum spp.

\section{Resumo}

A cana-de-açúcar (Saccharum spp.) é uma espécie pertencente à família Poaceae, extremamente importante para o cultivo comercial em diferentes partes do mundo. O presente trabalho teve como objetivo avaliar a influência da aplicação de diferentes doses de gesso agrícola nos parâmetros morfofisiológicos da cana-de-açúcar. O experimento foi conduzido na Usina Dracena, localizada em Dracena, Estado de São Paulo, em outubro de 2007, em cana de soqueira de quarto ciclo. O delineamento experimental foi em blocos casualizados, com quatro repetições. Os tratamentos foram cinco doses de gesso agrícola: $0 ; 1 ; 2 ; 4 \mathrm{e}$ $8 \mathrm{t} \mathrm{ha}^{-1}$, aplicadas em área total da parcela na instalação do experimento. Após a colheita de colmos, foram coletadas folhas para realização de análises morfológicas. A aplicação do gesso agrícola resultou em aumento no número de estômatos na face abaxial das folhas. A aplicação de gesso agrícola no solo proporcionou modificações favoráveis na morfofisiologia das folhas da soqueira de cana-de-açúcar.

Palavras-chave adicionais: fisiologia vegetal; morfologia vegetal; Saccharum spp.

\section{Introduction}

The sugarcane (Saccharum spp.) is a species of the family Poaceae, extremely important for commercial growing in different parts of the world. Particularly, Brazil has a production history that refers to more than four centuries (Martins \& Castro, 1999), strongly influencing the economy and social aspects of the country.

Since the 1970s, when the Brazilian government introduced the Pro-Alcohol, sugar and ethanol industry took a prominent position in the production of sugar derived from sugarcane and searching alternatives to fossil fuel, being it nowadays at the forefront of technology, thanks to the improved technology used over the years, notably with the development of new cultivars, machine and equipment optimization, use of pesticides, among many others.

The increased supply of sugarcane is extremely important to the growth of the sugar-energy sector. However, the demand for renewable products often encourages the use of areas hitherto marginal to agriculture, such as the Dracena region, State of São Paulo, which have low natural fertility and high sand content soils. 
The observation of plant anatomy is an important tool to assess the effects of culture conditions in plants (Castro et al., 2009). It can be modified by the presence of phytoregulators such as ethephon and gibberellins, which promote changes in bulliform cells in the vascular bundles and in the sclerenchyma fibers in leaves and stem (Martins \& Castro, 1999). The leaf anatomy of sugarcane plants can still be modified in salinity stress conditions, which changes the size of the midrib, mesophyll, the distance between the vascular bundles, the leaf epidermis and the area of vascular bundles (Akhtar et al., 2001). The anatomical characteristics of the sugarcane can also assign different levels of tolerance to the genotypes for drought conditions (Neufeld et al., 1992).

Rocha (2008) verified increases in the percentage of sucrose (pol) and total recoverable sugar (TRS), when applying mineral gypsum in sugarcane. However, it did not happen the same with the yield of stems, which did not have significant changes, corroborating with results obtained by Lima et al. (2010), who verified significant positive effects only in TRS and pol.

The application of agricultural gypsum is effective in reducing aluminum saturation (Bakker et al., 1999), reducing acidity in depth, increase of base saturation (Morelli et al., 1987) and improvement of the root system of cultivated plants (Prado, 2003). In addition, it contributes to the nutritional supply of calcium and sulfur (Caires et al., 2002), as well as to the distribution of bases along the soil profile (Demattê, 2004).

In Brazil, the most widely used gypsum in agriculture has residual origin, internationally known as phosphogypsum or fosfogesso, derived from the production of phosphoric acid, used in the manufacture of phosphate fertilizers, such as triple superphosphate (Malavolta, 1979). On average, it contains 180 and $150 \mathrm{~g} \mathrm{~kg}^{-1}$ of calcium and sulfur respectively, as well as impurities beneficial to agriculture, such as $7.5 \mathrm{~g} \mathrm{~kg}^{-1}$ of $\mathrm{P}_{2} \mathrm{O}_{5}$ and $6.3 \mathrm{~g} \mathrm{~kg}^{-1}$ of fluorides (Vitti et al., 2008), as well as traces of the elements zinc, copper and boron (Malavolta, 1992). It stands out also by promoting an increase in foliar contents of magnesium, potassium and phosphorus (Saldanha et al., 2007).

Saldanha (2005), working with particle sizes and doses of agricultural gypsum of mineral origin in sugarcane, verified significant effects on productivity. Foltran (2008), working with gypsum, silicates and limestone, verified that the agricultural gypsum gave positive responses when applied together with other inputs.

Fernandes et al. (2007) found differences in productivity according to the application of gypsum, corroborating Morelli et al. (1987) and Corrêa et al. (1999), in contrast with results of Azeredo et al. (1996), who found no significant effects of gypsum in yield of sugarcane.

Using agricultural gypsum as a source of calcium and sulfur for sugarcane, Fernandes (1985) concluded that small amount applied in the planting row $\left(50 \mathrm{~kg} \mathrm{ha}^{-1}\right)$ provided better plant growth. At higher doses, like $500 \mathrm{~kg} \mathrm{ha}^{-1}$, the increase in productivity was significant. Fernandes et al., (2007), working with the application of agricultural gypsum at different doses, found significant increases in the yield of sugarcane.

Calcium is an extremely important nutrient for the root growth of plants (Ritchey et al., 1980). Deficiency symptoms first appear in the meristematic regions, due to their presence in the composition of the cell wall, being therefore essential for the cell elongation and division (Epstein \& Bloom, 2004). The supply via calcium liming in deficient soils, fertilization or gypsum, becomes vital to the good development of root system. Due to its immobility in phloem, which prevents the internal movement of the nutrient to the growing points of the roots, there is the need for its presence so that there is an adequate cell elongation and division in this region (Epstein \& Bloom, 2004, Malavolta, 2006). The agricultural gypsum provides the nutrient calcium to the deeper layers with no need for incorporation, due to its greater mobility in the soil, increasing its content and base saturation, but does not act as a pH corrective (Caires et al., 1998, Demattê, 2004).

The deeper morphophysiological knowledge of plants and transformations motivated by the environmental variations, or the very nature of cultivars, is essential because the changes visible to the naked eye are derived from structural changes in dermal, fundamental and vascular tissues (Castro et al., 2009).

The plant anatomy may indicate features that give tolerance to different environmental conditions for crops such as drought, flood or quality and intensity of the radiation falling on the leaves, and can promote changes in the thickness of the mesophyll, vascular tissues, thickness of the epidermis, cuticle thickness and stomatal density (Gardoni et al., 2007, Castro et al., 2009, Ribeiro et al., 2012, Pincelli \& Silva, 2012).

The information in the literature on the effects of gypsum on leaf morphology of sugarcane are scarce. In this sense, this study aimed to evaluate the morphophysiological parameters of sugarcane leaf in response to the residual effect of agricultural gypsum on the ratoon.

\section{Material and methods}

The experiment was installed in sugar-ethanol unit of Dracena Plant, located in Dracena, State of Sao Paulo, with geographical coordinates $21^{\circ} 32 ' 31^{\prime \prime} \mathrm{S}$ and 51⒋ $41^{\prime} 47^{\prime \prime} \mathrm{W}$ and $322 \mathrm{~m}$ altitude, in October 2007, in fourth cycle ratoon cane, newly harvested from third cycle.

The climate of the city is characterized as Cwa, according to Köppen, mesothermal, with rainy summers and average air temperature, in the warmest month, greater than $22^{\circ} \mathrm{C}$. The average temperature is $24^{\circ} \mathrm{C}$, with maximum of $31^{\circ} \mathrm{C}$ and 
minimum of $19 \stackrel{\circ}{ } \mathrm{C}$. The average rainfall in the last 10 years was $1510 \mathrm{~mm}$, with the higher rates in the months of November, December, January and February.

The soil was classified as dystrophic RedYellow Latosol (dRYL), of sandy loam texture and gently rolling relief (Embrapa, 2006). A soil sample was collected by the time of the experiment and the depths of soil sampling along the profile were 0-0.2 and 0.2-0.4 meters.

The major chemical attributes of the soil were determined, such as $\mathrm{pH}, \mathrm{M} . \mathrm{O} ., \mathrm{P}, \mathrm{S}, \mathrm{K}, \mathrm{Ca}, \mathrm{Mg}, \mathrm{Al}$, $\mathrm{H}+\mathrm{Al}, \mathrm{T}, \mathrm{V}, \mathrm{M}, \mathrm{B}, \mathrm{Cu}, \mathrm{Fe}, \mathrm{Mn}$ and $\mathrm{Zn}$, before applying treatments in different layers up to $0.4 \mathrm{~m}$ deep, according Raij et al. (1996). Data are shown on Table 1.

Table 1 - Chemical soil parameters before application of treatments, in October 2007.

\begin{tabular}{cccccccccccccccccc}
\hline Layer & $\mathrm{pH}$ & $\mathrm{M} . \mathrm{O}$. & $\mathrm{P}$ & $\mathrm{S}$ & $\mathrm{K}$ & $\mathrm{Ca}$ & $\mathrm{Mg}$ & $\mathrm{Al}$ & $\mathrm{H}+\mathrm{Al}$ & $\mathrm{T}$ & $\mathrm{V}$ & $\mathrm{M}$ & $\mathrm{B}$ & $\mathrm{Cu}$ & $\mathrm{Fe}$ & $\mathrm{Mn}$ & $\mathrm{Zn}$ \\
\hline$(\mathrm{m})$ & \multicolumn{1}{c}{$\left(\mathrm{g} \mathrm{dm}^{-3}\right)$} & $\left(\mathrm{mg} \mathrm{dm}^{-3}\right)$ & $\ldots \ldots \ldots \ldots \ldots$. & $\left(\mathrm{mmol}_{\mathrm{c}} \mathrm{dm}^{-3}\right) \ldots \ldots \ldots \ldots$ & $\ldots .(\%)$ & $\ldots \ldots$ & $\ldots \ldots \ldots \ldots . .\left(\mathrm{mg} \mathrm{dm}^{-3}\right) \ldots \ldots \ldots \ldots$ \\
$0.0-0.2$ & 4.5 & 17 & 3 & 9 & 0.7 & 7 & 4 & 4 & 18 & 29.7 & 39 & 25 & 0.6 & 0.5 & 19 & 4.5 & 0.3 \\
$0.2-0.4$ & 4.0 & 13 & 2 & 8 & 0.2 & 3 & 1 & 6 & 22 & 26.2 & 16 & 59 & 0.5 & 0.6 & 14 & 3.0 & 0.1 \\
\hline
\end{tabular}

The experimental design was in randomized blocks with five treatments and four repetitions. The used treatments were five doses of agricultural gypsum as follows: $0 ; 1 ; 2 ; 4$ and $8 \mathrm{tha}^{-1}$, applied to the total area of each plot in the experiment installation in October 2007.

The plots, or experimental units, were composed of eight rows of sugarcane spaced 1.40 meters by 12 meters in length, totaling $134.4 \mathrm{~m}^{2}$. To obtain the useful area, $84.0 \mathrm{~m}^{2}$ were considered, being discarded one row on each side of the plot and 1.0 meter of each end.

The agricultural gypsum used in the experiment was from residue of the manufacture of phosphoric acid by the company Copebrás from Cubatão, State of São Paulo. It had branny granulometry and yellowish color, with a concentration of $204.5 \mathrm{~g} \mathrm{~kg}^{-1}$ of $\mathrm{Ca}$ and $162.3 \mathrm{~g} \mathrm{~kg}^{-1}$ of $\mathrm{S}$. The Chelatometric method was used to determine the calcium content and the method of Turbidimetry of Barium Sulphate, for S (Lanarv, 1988).

In the sugarcane plantations, the cultivar chosen for the installation was the RB 86-7515, because of its rusticity to environments of medium and low fertility and good adaptability to sandy and medium textured soils. It shows good ratoon emergence (Hoffmann et al., 2008).

The choice of the area was due to the possibility of reply to the application of agricultural gypsum, according to the uniformity of the ratoon; soil type; area size; homogeneity of the field; proper distance from the terrace; absence of anthills; slope for water draining and easy access. Specific herbicides were used for weed control.

At the stem harvest in October 2009, ie, two years after the application of the agricultural gypsum, leaves were collected to perform the morphological analysis.

In each plot, 10 pieces of leaves +1 distinct, was removed randomly collected at different points of the experimental plot. Each fragment was $5 \mathrm{~cm}$ long extracted from the central part of leaf blade. The samples were sent to the Laboratory of Vegetable Morphophysiology Laboratory and Forage of Universidade Estadual Paulista "Júlio de Mesquita Filho" - Campus Experimental de Dracena, located in Dracena, State of São Paulo. To perform the leaf morphoanatomical analysis all collected material was fixed in F.A.A. 70 solution (37\% formaldehyde, acetic acid and $70 \%$ ethanol at a ratio of 1.0:1.0:18.0 - V/V). After 24 hours, they were washed in $70 \%$ ethanol and stored in $70 \%$ ethanol until the date of the analysis, according to Kraus \& Arduim (1997).

All plant tissue fragments received the relevant procedures to dehydration, diaphanization, inclusion and embedment. With the aid of a Leica table microtome containing steel blade, cross sections of $8 \mu \mathrm{m}$ were made on each embedded leaf fragment. For the assembly of histological slides the first cross-sections that showed the best preserved material, ie, without damage or injury caused by cutting the plant tissue, were chosen. All chosen sections were fixed with Mayer adhesive, stained with $1 \%$ safranin and mounted on slides and coverslips with Entellan adhesive. All slides were observed under an optical microscope Leica, with a camera attached to take photographs of the cuts. The photographs were used for measurements of anatomical parameters through the QWin image analysis software, calibrated with microscopic ruler at the same photograph increases, according to the methodology described by Pereira et al. (2008).

In the abaxial and adaxial leaves faces, the following characteristics were evaluated through the method of epidermal face printing with use of cyanoacrylate ester: NE - number of stomata per field; NC - number of epidermal cells per field; POL - polar diameter of the stomata; QUE - equatorial diameter of the stomata; DE - stomatal density; FUN - stomatal functionality; IE - stomatal index (Segatto et al., 2004, Castro et al., 2009). 


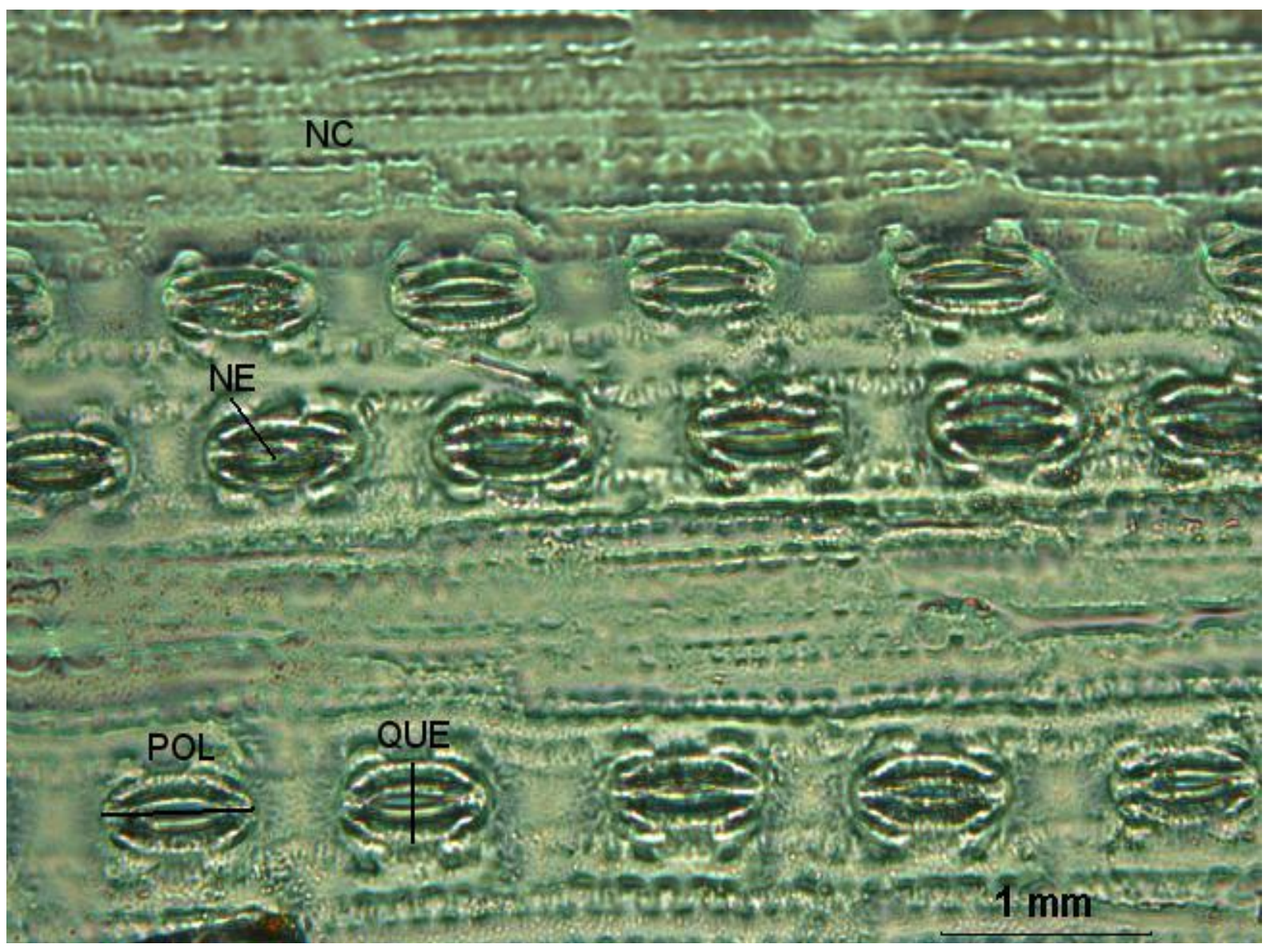

Figure 1 - Abaxial face of sugarcane leaf. NE - number of stomata per field; NC - number of epidermal cells per field; POL - polar diameter of the stomata; and QUE equatorial diameter of the stomata.

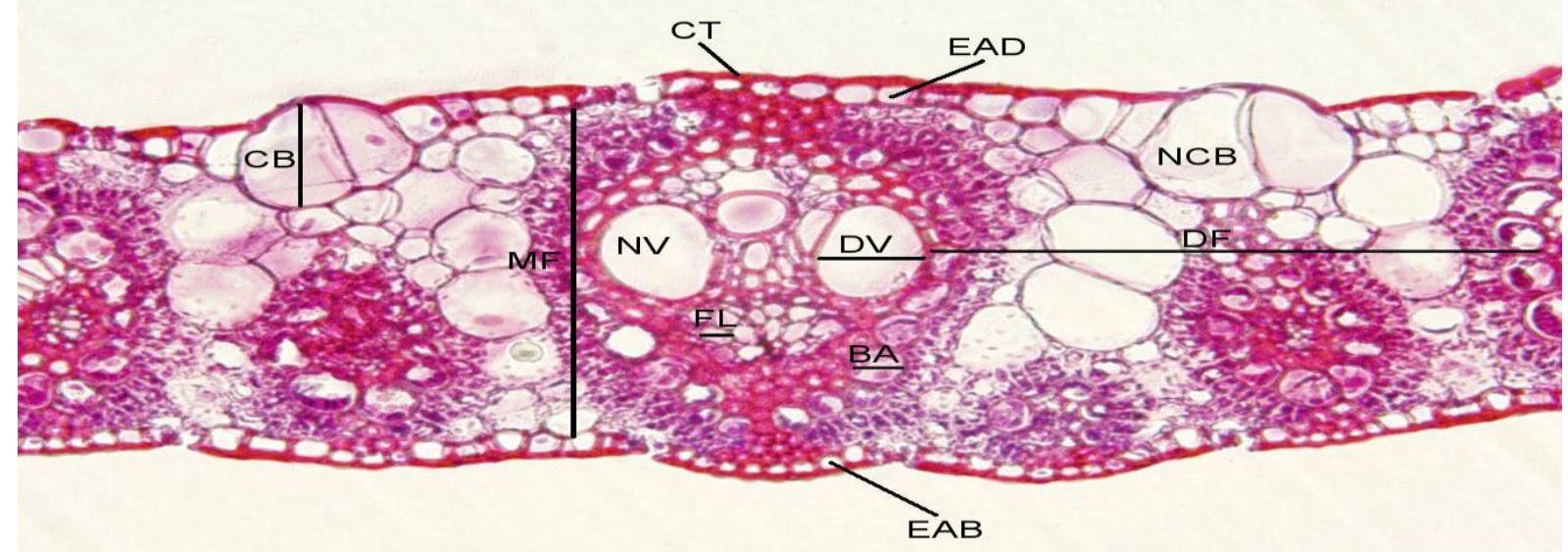

$\overline{50 \mu \mathrm{m}}$

Figure 2 - Cross section of the sugarcane leaf. EAB - thickness of the epidermis of the abaxial face; EAD - thickness of the epidermis of the adaxial face; MF - thickness of the mesophyll; CT - thickness of the upper cuticle; $C B$ - the polar diameter of bulliform cells; NCB - number of bulliform cells per mm; $\mathrm{BA}$ - diameter of the bundle sheath cells; FL - phloem thickness; NV - number of metaxylem vessels in the midrib; DV - diameter of the metaxylem vessels in the midrib; IVC - vulnerability index of the vascular system and DF - distance between the vascular bundles in the leaf blade. 
In cross sections of leaves following characteristics were evaluated: EAB - thickness of the epidermis of the abaxial face; EAD - thickness of the epidermis of the adaxial face; MF - thickness of the mesophyll; CT - thickness of the upper cuticle; CB the polar diameter of bulliform cells; NCB - number of bulliform cells per mm; BA - diameter of the bundle sheath cells; FL - phloem thickness; NV - number of metaxylem vessels in the midrib; DV - diameter of the metaxylem vessels in the midrib; IVC - vulnerability index of the vascular system and DF - distance between the vascular bundles in the leaf blade, according Carlquist (1975).

For all characteristics, five measurements per slide were performed. The plots were represented by the average value obtained for each characteristic. All characteristics were submitted to the analysis of variance by $F$ Test $(p<0.05)$ and the Scott-Knott mean test.

\section{Results and discussions}

In general, the different doses of agricultural gypsum applied to the soil promoted changes in leaf anatomy of sugarcane ratoon, since one of the great advantages of this input is the supply of sulfur, limiting nutrient for the production of essential amino acids, such as cysteine and methionine, essential for the formation of proteins (Caires et al., 2002). The gypsum acts as a supplier of enzyme activator ele- ments that participate in all the metabolic processes of the plant, especially photosynthesis, respiration, synthesis of fats, formation of proteins and fixation of N2 (Epstein \& Bloom, 2004, Malavolta, 2006).

In the abaxial or lower face of the leaves, the number of stomata per field increased when agricultural gypsum was applied in the soil (Table 2). Similarly, the stomatal density increased when gypsum was applied, with a higher value when applied $8 \mathrm{tha}^{-1}$ of input in the soil. The increase of this characteristic with the dose of $8 \mathrm{t} \mathrm{ha}^{-1}$ showed also an increase of approximately $16.0 \%$ as compared to the control treatment. The different environmental conditions to which the cultivated species are subject can promote changes in the anatomy and physiology of different organs, such as leaves and roots (Pereira et al., 2008, Souza et al., 2009, Pereira et al., 2010, Souza et al., 2010). Still in the abaxial face, there was no significant difference between treatments for the characteristics number of epidermal cells per field; polar diameter of the stomata; equatorial diameter of the stomata; stomatal functionality; and stomatal index. The increase in stomatal density in the abaxial surface is directly related to the increase in the number of stomata observed in the treatments containing agricultural gypsum. According to Castro et al. (2009), the increase in the stomatal density is directly related to the capacity to incorporate $\mathrm{CO}_{2}$ in the leaves.

Table 2 - Anatomical characteristics of sugarcane leaves (Saccharum spp.) subjected to different doses of agricultural gypsum applied to the soil at harvest in 2009, two years after the treatment application.

\begin{tabular}{|c|c|c|c|c|c|c|c|}
\hline \multirow[b]{2}{*}{ Treatments } & \multicolumn{7}{|c|}{ Abaxial face } \\
\hline & ${ }^{1} \mathrm{NE}$ & ${ }^{2} \mathrm{NC}$ & ${ }^{3} \mathrm{POL}$ & ${ }^{4}$ QUE & ${ }^{5} \mathrm{DE}$ & ${ }^{6} \mathrm{FUN}$ & ${ }^{\prime} I E$ \\
\hline $0 \mathrm{t} \mathrm{ha}^{-1}$ & $11.75 \mathrm{~b}$ & 58.50 & 44.84 & 26.09 & $150.89 \mathrm{c}$ & 1.72 & 0.20 \\
\hline $1 \mathrm{tha}^{-1}$ & $12.38 \mathrm{a}$ & 61.00 & 46.22 & 27.57 & $158.92 b$ & 1.68 & 0.20 \\
\hline $2 \mathrm{t} \mathrm{ha}^{-1}$ & $12.50 \mathrm{a}$ & 58.63 & 45.89 & 25.22 & $160.52 \mathrm{~b}$ & 1.82 & 0.21 \\
\hline $4 \mathrm{tha}^{-1}$ & $12.38 \mathrm{a}$ & 61.38 & 45.80 & 26.37 & $158.92 b$ & 1.74 & 0.20 \\
\hline $8 \mathrm{tha}^{-1}$ & $13.63 \mathrm{a}$ & 63.00 & 45.44 & 25.62 & $174.97 \mathrm{a}$ & 1.77 & 0.22 \\
\hline \multirow[b]{2}{*}{ Treatments } & \multicolumn{7}{|c|}{ Adaxial face } \\
\hline & ${ }^{1} \mathrm{NE}$ & ${ }^{2} \mathrm{NC}$ & ${ }^{3} \mathrm{POL}$ & ${ }^{4}$ QUE & ${ }^{5} \mathrm{DE}$ & ${ }^{6} \mathrm{FUN}$ & ${ }^{7} \mathrm{IE}$ \\
\hline $0 \mathrm{t} \mathrm{ha}^{-1}$ & $6.38 \mathrm{~b}$ & 53.50 & 46.23 & 25.08 & $81.87 \mathrm{~b}$ & 1.84 & $0.12 \mathrm{~b}$ \\
\hline $1 \mathrm{tha}^{-1}$ & $6.38 \mathrm{~b}$ & 54.00 & 47.11 & 25.49 & $81.87 \mathrm{~b}$ & 1.85 & $0.12 b$ \\
\hline $2 \mathrm{tha}^{-1}$ & $6.38 \mathrm{~b}$ & 46.25 & 47.03 & 25.20 & $81.87 \mathrm{~b}$ & 1.87 & $0.14 \mathrm{a}$ \\
\hline $4 \mathrm{tha}^{-1}$ & $7.13 \mathrm{a}$ & 46.00 & 46.78 & 25.16 & $91.50 \mathrm{a}$ & 1.86 & $0.16 \mathrm{a}$ \\
\hline $8 \mathrm{tha}^{-1}$ & $7.25 \mathrm{a}$ & 50.88 & 46.88 & 25.28 & $93.10 \mathrm{a}$ & 1.85 & $0.14 \mathrm{a}$ \\
\hline
\end{tabular}

Different means in column differ by Scott-Knott test at $p<0.05 .{ }^{1}$ number of stomata per field; ${ }^{2}$ the number of epidermal cells per field; ${ }^{3}$ polar diameter of the stomata; ${ }^{4}$ equatorial diameter of the stomata; ${ }^{5}$ stomatal density (stomata per $\left.\mathrm{mm}^{2}\right) ;{ }^{6}$ stomatal functionality (ratio POL/QUE); ${ }^{7}$ stomatal index.

In adaxial or upper face of the leaves, there was an increase in the number of stomata at doses of 4.0 and $8.0 \mathrm{t} \mathrm{ha}^{-1}$, which resulted in increased stomatal density at the same doses (Table 2). The stomatal index was increased in treatments receiving at least $2.0 \mathrm{t} \mathrm{ha}^{-1}$ of agricultural gypsum. This demonstrates the positive effect of higher doses of agricultural gypsum to the stomata in the epidermis of sugarcane leaves, probably due to the action of calcium that is directly centered on the structural part of the cell wall. It is worth noting that approximately $60 \%$ of this nutrient is found in the form of 
calcium pectate, acting in the formation of pectin, essential for cell elongation (Tobias et al., 1993). However, in the adaxial face, the application of gypsum did not promote significant changes in the number of epidermal cells per field; in the polar diameter of the stomata; in the equatorial diameter of the stoma, as well as in their functionality.

Stomatal density and stomatal index may change depending on the environmental conditions, according to Grisi et al. (2008), Souza et al. (2010). Thus, the increased stomatal density and stomatal index observed in the sugarcane leaves subjected to different concentrations of agricultural gypsum can give better conditions for $\mathrm{CO}_{2}$ capture and promote photosynthesis. On the other hand, the absence of changes in the size and functionality of the stomata in the presence of agricultural gypsum enables these stomata to remain functional, showing no evidence of toxicity, which could lead to loss of stomatal functionality.
The epidermis of abaxial and adaxial faces of sugarcane leaves, as well as the mesophyll, showed increased thickness in all treatments containing agricultural gypsum, compared to the control treatment. The application of agricultural gypsum in the soil can cause changes in morphophysiological aspects of sugarcane leaves, providing changes in crop yield, since the calcium in this input comprises cell membranes, preventing the leakage of cytoplasmic contents and acts as enzyme regulator (Malavolta, 2006).

There were no significant differences in the thickness of the upper cuticle, in the polar diameter and number of bulliform cells (Table 3 ).

Different environmental conditions can provide changes in the thickness of the epidermis of sugarcane leaves (Akhtar et al., 2001), as well as other in species, such as corn (Souza et al., 2010) or even in other plant organs (Pereira et al., 2008, Souza et al., 2009).

Table 3 - Anatomical characteristics of sugarcane leaves (Saccharum spp.) in cross section subjected to different doses of agricultural gypsum to the soil at harvest in 2009, two years after the treatment application.

\begin{tabular}{|c|c|c|c|c|c|c|}
\hline \multirow{2}{*}{ Treatments } & \multicolumn{6}{|c|}{ Leaf blade tissues } \\
\hline & ${ }^{1} \mathrm{EAB}$ (um) & ${ }^{2} \mathrm{EAD}$ (um) & ${ }^{3} \mathrm{MF}(\mathrm{um})$ & ${ }^{4} \mathrm{CT}$ (um) & ${ }^{5} \mathrm{CB}$ (um) & ${ }^{6} \mathrm{NCB}$ \\
\hline $1\left(0 \mathrm{t} \mathrm{ha}^{-1}\right)$ & $16.38 \mathrm{~b}$ & $22.50 \mathrm{~b}$ & $355.34 \mathrm{~b}$ & 13.36 & 142.09 & 13.50 \\
\hline $2\left(1 \mathrm{t} \mathrm{ha}^{-1}\right)$ & $19.69 \mathrm{a}$ & $24.86 \mathrm{a}$ & $433.98 \mathrm{a}$ & 12.78 & 148.29 & 12.00 \\
\hline $3\left(2 \mathrm{t} \mathrm{ha}^{-1}\right)$ & $19.85 a$ & $26.92 \mathrm{a}$ & $425.29 \mathrm{a}$ & 12.86 & 149.26 & 12.38 \\
\hline $4\left(4 \mathrm{t} \mathrm{ha}^{-1}\right)$ & $19.61 \mathrm{a}$ & $23.52 \mathrm{a}$ & $398.15 \mathrm{a}$ & 13.29 & 147.30 & 12.13 \\
\hline $5\left(8 \mathrm{t} \mathrm{ha}^{-1}\right)$ & $20.01 \mathrm{a}$ & $24.94 \mathrm{a}$ & $370.88 \mathrm{a}$ & 14.88 & 155.55 & 12.25 \\
\hline \multirow{2}{*}{ Treatments } & \multicolumn{6}{|c|}{ Characteristics of vascular bundles } \\
\hline & ${ }^{\mathrm{B} A}$ (um) & ${ }^{8} \mathrm{FL}$ (um) & ${ }^{9} \mathrm{NV}$ & ${ }^{10} \mathrm{DV}$ (um) & ${ }^{11}$ IVC & ${ }^{12} \mathrm{DF}$ (um) \\
\hline $1\left(0 \mathrm{t} \mathrm{ha}^{-1}\right)$ & 32.10 & $73.78 \mathrm{~b}$ & $21.13 \mathrm{~d}$ & $70.77 \mathrm{a}$ & $3.35 \mathrm{a}$ & 105.30 \\
\hline $2\left(1 \mathrm{t} \mathrm{ha}^{-1}\right)$ & 33.95 & $87.32 \mathrm{a}$ & $21.75 \mathrm{~d}$ & $68.98 \mathrm{a}$ & $3.19 \mathrm{a}$ & 098.62 \\
\hline $3\left(2 \mathrm{t} \mathrm{ha}^{-1}\right)$ & 35.27 & $79.94 \mathrm{a}$ & $25.13 \mathrm{c}$ & $62.84 \mathrm{~b}$ & $2.54 b$ & 108.34 \\
\hline $4\left(4 \mathrm{t} \mathrm{ha}^{-1}\right)$ & 34.70 & $82.30 \mathrm{a}$ & $29.13 b$ & $63.03 \mathrm{~b}$ & $2.20 \mathrm{~b}$ & 101.72 \\
\hline $5\left(8 \mathrm{t} \mathrm{ha}^{-1}\right)$ & 37.84 & $83.73 \mathrm{a}$ & $34.00 \mathrm{a}$ & $75.52 \mathrm{a}$ & $2.26 \mathrm{~b}$ & 111.94 \\
\hline
\end{tabular}

Different means in column differ by Scott-Knott test at $\mathrm{P}<0.05 .(1)=$ thickness of the abaxial face epidermis. $(2)=$ thickness of the adaxial face epidermis. (3) = thickness of the mesophyll. (4) = thickness of the upper cuticle. (5) = polar diameter of bulliform cells. $(6)=$ number of bulliform cells per mm. $(7)=$ diameter of the bundle sheath cells. (8) = phloem thickness. (9) $=$ number of metaxylem vessels in the midrib. $(10)=$ diameter of the metaxylem vessels in the midrib. $(11)=$ vulnerability index of the vascular system (12) = distance between the vascular bundles in the leaf blade.

The epidermis, being an outer tissue, is the one that initially is exposed to the environment and receives environmental pressures. The thickening of the leaf epidermis can be important to reduce water loss and attenuate the incident radiation (Castro et al., 2009). Thus, the thickening of the epidermis in the upper and lower faces observed in the presence of gypsum when applied to the soil may be a favorable characteristic for the sugarcane plants, for partially reducing the effects of xeric environments, which have lower water availability.

In another aspect, the sugarcane can demonstrate changes in mesophyll according to environmental conditions (Akhtar et al., 2001). The thickening observed in the mesophyll is interesting because, according to Castro et al. (2009), it may be important for species subject to large radiation intensities. The results agree with Melo et al. (2004) who also state that calcium caused a significant increase in thickening of epidermis and mesophyll, compared to treatment without the addition of this element in corn plants.

The differences in the anatomy of sugarcane are important for selecting genotypes tolerant to water stress (Neufeld et al., 1992). Thus, the thickening of the mesophyll in the presence of gypsum can be beneficial to the cultivation of sugarcane in regions like Cerrado, which commonly have excess of solar radiation. In addition, the benefits attributed to Cerrado soil by applying gypsum, as reported by Bernardes et al. (2007), must be considered. 
The absence of changes in the thickness of the cuticle and in bulliform cells in the presence of gypsum may be related to the non-occurrence of toxicity to the leaves, since, under stress conditions, the bulliform cells may be modified (Martins \& Castro, 1999).

In the midrib, the most significant changes occurred in the vascular bundles, as shown on Table 3. There was an increase in the thickness of the phloem in treatments containing gypsum, compared to the control treatment. Phloem is an essential tissue for translocation of photosynthates (Castro et al., 2009) and can be modified in different environmental conditions (Pereira et al., 2008, Souza et al., 2009). Thickening of phloem observed in plants belonging to the treatments containing gypsum can be a relevant factor for the translocation of photoassimilates to the stem and roots, improving the development of these organs, as well as the accumulation of sugars in the stem of sugarcane. Phloem is essential to the translocation of photoassimilates from the aerial part to the roots and can thicken depending on environmental characteristics (Pereira et al., 2008, Souza et al., 2009).

The number of metaxylem vessels in the midrib has changed considerably in the treatments containing gypsum starting at the dose of $2 \mathrm{tha}^{-1}$. Results were contradictory for the characteristic diameter of the metaxylem vessels in the midrib, with no significant differences between the highest dose and control treatment, as described on Table 3 . The changes observed in the xylem give greater hydraulic conductivity to plants in treatments containing gypsum, due to the increase in the number of vessels, as well as the reduction in their diameter and in the vulnerability index of the vascular system, allowing the increase in hydraulic conductivity, by reducing the probability of embolism (Carlquist, 1975).

These changes promoted a decrease in the vulnerability index of the vascular system in treatments containing gypsum starting at the dose of $2 \mathrm{tha}^{-1}$. No significant changes were found to the diameter of the bundle sheath cells, neither in the distance between the vascular bundles in the leaf blade. The reduction of IVC is a characteristic of tolerance for species subjected to environmental stress and can occur in roots and leaves (Pereira et al., 2008, Souza et al., 2010).

In general, the results obtained for the morphophysiological characteristics may have occurred due to the presence of the element sulfur, component of the agricultural gypsum, which probably provided significant foliar answers of this nutrient. The results are in agreement with those found by Gallo \& Hiroce (1968), Raij \& Cantarella (1996) and Malavolta (1992).

\section{Conclusions}

The application of agricultural gypsum in the soil provided favorable changes in the leaves morphophysiology of sugarcane ratoon.

\section{References}

Akhtar S, Wahid A, Akran M, Rasul E (2001) Some growth photosynthetic and anatomical attributes of sugarcane genotypes under $\mathrm{NaCl}$ salinity. International Journal of Agriculture e Biology 3(4): 439-443.

Azeredo DF, Bolsanello J, Manhães MS, Weber H (1996) Doses de calcário, gesso, mistura de calcário/gesso, interação calcário $x$ fósforo e calcário $x$ potássio em cana-de-açúcar. In: Congresso nacional da sociedade dos técnicos açucareiros e alcooleiros do Brasil, 6th ed., Stab. p.477-483.

Bakker MR, Nys C, Picard JF (1999) The effects of liming and gypsum applications on a sessile oak (Quercus petraea (M.) Liebl) stand at La Croix-Scaille (French Ardennes). Site characteristics, soil chemistry and aerial biomass. Plant and Soil 206:9-108.

Bernardes MB, Freire FJ, Costa FGB (2007) Gesso mineral como fonte de enxofre para cana-de-açúcar. Caatinga 4(20):101-109.

Caires EF, Chueri WA, Madruga EF, Figueiredo A (1998) Alterações de características químicas do solo e resposta da soja ao calcário e gesso aplicados na superfície em sistema de cultivo sem preparo do solo. Revista Brasileira de Ciência do Solo 22:27-34.

Caires EF, Feldhaus IC, Barth G, Garbuio FJ (2002) Lime and Gypsum application in the wheat crop. Sciencia Agricola 59(2):357-364.

Carlquist S (1975) Ecological strategies of xylem evolution. University of California Press. 259p.

Castro EM, Pereira FJ, Paiva R (2009) Histologia Vegetal: Estrutura e Função de Órgãos Vegetativos. UFLA/FAEPE. 234 p.

Corrêa JBD, Andrade LAB, Rosa JH, Ferreira Neto AE (1999) Efeitos da aplicação de gesso mineral em três variedades de cana-de-açúcar cultivadas em Podzólico Vermelho-Amarelo. Stab: Açúcar e Álcool 17:38-42.

Demattê JLI (2004) Recuperação e manutenção da fertilidade dos solos. Revista Visão Agrícola 1:49-52.

Embrapa-Centro Nacional de Pesquisa Agropecuária de Solos (2006) Sistema brasileiro de classificação de solos, $2^{\mathrm{a}}$ ed, Embrapa-SPI. 306p.

Epstein E, Bloom A (2004) Nutrição mineral de plantas: princípios e perspectivas. Editora Planta. 403p.

Fernandes FA (1985) Efeito do gesso como fonte de cálcio e de enxofre na cultura da cana-de-açúcar (Sacaharum officinarum L.). Universidade de São Paulo (Dissertação de mestrado em Agronomia).

Fernandes MB, Freire FJ, Costa FGB (2007) Gesso mineral como fonte de enxofre para cana-de-açúcar. Revista Caatinga 20(4):101-109. 
Foltran R (2008) Aplicação de calcário, silicato e gesso em soqueira de cana-de-açúcar sem despalha a fogo. Unesp (Dissertação de mestrado em Agronomia).

Gallo JR, Hiroce R (1968) Levantamento do estado nutricional de canaviais de São Paulo, pela análise foliar. Bragantia 27(30):365-382.

Gardoni LCP, Isaias RMS, Vale FHA (2007) Morfologia e anatomia foliar de três morfotipos de Marcetia taxifolia (A.St.-Hil) DC. (Melastomataceae) na Serra do Cipó, MG. Revista Brasileira de Botânica 30(3):487-500.

Grisi, FA, Alves JD, Castro EM, Oliveira C, Biagiotti G, Melo LA (2008) Avaliações anatômicas foliares em mudas de café 'Catuaí' e 'Siriema' submetidas ao estresse hídrico. Ciência e Agrotecnologia 32(6):1730-1736.

Hoffmann HP, Santos EGD, Bassinello AIV, Vieira MAS (2008) Variedades RB de cana-de-açúcar. CCA/UFSCar. 30p.

Kraus JE, Arduim M (1997) Manual básico em métodos em morfologia vegetal. EDU. 221p.

Lanarv-Laboratório Nacional de Referência Vegetal (1988) Análise de corretivos, fertilizantes e inoculantes. Métodos oficiais. Ministério da Agricultura. 104p.

Malavolta $E$ (1992) ABC da análise de solos e folhas: amostragem, interpretação e sugestões de adubação. Ed. Agronômica Ceres. 124p.

Malavolta E (1979) Tecnologia de fertilizantes para o Brasil. In: Simpósio sobre tecnologia da academia de ciências do Estado de São Paulo, Anais... [S.I.: s.n.]. $24 p$.

Malavolta E (2006) Manual de nutrição mineral de plantas. Ed. Agronômica Ceres. 638p.

Martins MBG, Castro PRC (1999) Efeitos de giberelina e ethephon na anatomia de plantas de cana-deaçúcar. Pesquisa Agropecuária Brasileira 34(10):1855-1863.

Melo HC, Castro EM, Romero JL, Alves JD, Fries DD, Melo LA, Magalhães PC (2004) Influência da aplicação da cálcio e alagamento do solo sobre características anatômicas das folhas de milho (Zea mays L.) "Saracura" BRS-4154. Revista Brasileira de Milho e Sorgo 3(3):333-342.

Morelli JL, Nelli EJ, Demattê JLI, Dalben AE (1987) Efeito do gesso e do calcário nas propriedades químicas de solos arenosos álicos e na produção de cana-de-açúcar. In: Congresso Brasileiro de Ciência do Solo, 21 $1^{\underline{a}}$ edn, Anais... Sociedade Brasileira de Ciência do Solo. $96 p$.
Neufeld HS, Grantz DA, Meinzer FC, Goldstein G, Crisosto GM, Crisosto C (1992) Genotypic variability in vulnerability of leaf xylem to cavitation in waterstressed and well-irrigated sugarcane. Plant Physiology 100:1020-1028.

Pereira FJ, Magalhães PC, Souza TC, Castro EM, Alves JÁ (2010) Evolução da anatomia radicular do milho 'Saracura' em ciclos de seleção sucessivos. Pesquisa agropecuária brasileira 45(5):450-456.

Pereira FJ, Castro EM, Souza TC, Magalhães PC (2008) Evolução da anatomia radicular do milho 'Saracura' em ciclos de seleção sucessivos. Pesquisa agropecuária brasileira 43(12):1649-1656.

Pincelli RP, Silva MA (2012) Alterações morfológicas foliares em cultivares de cana-de-açúcar em resposta à deficiência hídrica. Bioscience Journal 28(4):546-556.

Prado RM (2003) Efeito residual do calcário sob diferentes modos de incorporação antes da instalação do sistema plantio direto. Revista Brasileira de Engenharia Agrícola e Ambiental 7(3):478-482.

Raij B van, Cantarella H (1996) Outras culturas industriais. In: Raij B van, Cantarella H, Quaggio JA, Furlani AMC (coord) Recomendações de adubação e calagem para o Estado de São Paulo, 2nd edn, Fundação IAC. p.233-236.

Ribeiro MNO, Carvalho SP, Pereira FJ, Castro EM (2012) Leaf anatomy of the cassava as related to potencial for tolerance to diferente environmental conditions. Revista Ciência Agronômica 43(2):354361.

Ritchey KD, Sousa DMG, Lobato E, Correa O (1980) Calcium leaching to increase rooting depth in a Brazilian savannah oxisol. Agronomy Journal 72(1):40-44.

Rocha AT, Oliveira AC, Rodrigues NA, Lira Júnior MA, Freire FJ (2008) Emprego do gesso do Araripe na melhoria do ambiente radicular da cana-de-açúcar. Revista Brasileira Ciências Agrárias 3:307-312.

Saldanha ECM (2005) Gesso mineral em cana-deaçúcar: Efeitos no solo e na planta. Universidade Federal Rural de Pernambuco (Dissertação de mestrado em Agronomia).

Saldanha ECM, Rocha AT, Oliveira ECA, Nascimento CWA, Freire FJ (2007) Uso do gesso mineral em Latossolo cultivado com cana-de-açúcar. Revista Caatinga 20(1):36-42.

Segatto FB, Bisognin DA, Benedetti M, Costa LC, Rampelotto MV, Nicoloso FT (2004) Técnica para o estudo da anatomia da epiderme foliar de batata. Ciência Rural 34:1597-1601. 
Souza TC, Magalhães PC, Pereira FJ, Castro EM, Silva Júnior JM, Parentoni SN (2010) Leaf plasticity in successive selection cycles of 'Saracura' maize in response to periodic soil flooding. Pesquisa Agropecuária Brasileira 45:16-24.

Souza TC, Castro EM, Pereira FJ, Parentoni SN, Magalhães PC (2009) Morpho-anatomical characterization of root in recurrent selection cycles for flood tolerance of maize (Zea mays L.). Plant Soil and Environment 55(11):504-510.
Tobias RB, Conway WS, Sams CE, Gross KC, Whitakker BD (1993) Cell wall composition of calcium-treated apples inoculated with Botritis cinerea. Phytochemistry 32:35-39.

Vitti GC, Luz PHC, Malavolta E, Dias AS, Serrano CGE (2008) Uso do gesso em sistemas de produção agrícola. GAPE/Ed. Agronômica Ceres. 104 p. 